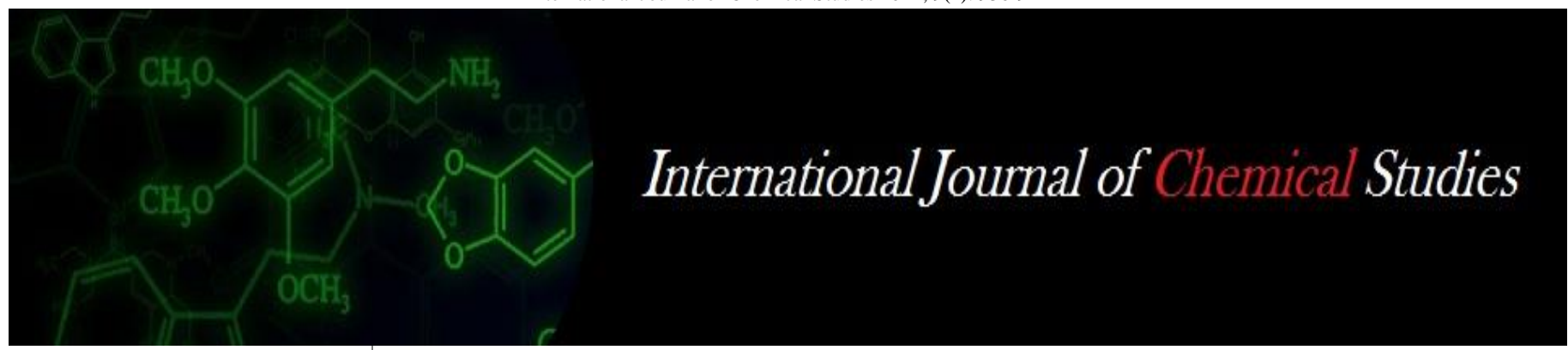

P-ISSN: 2349-8528

E-ISSN: 2321-4902

www.chemijournal.com

IJCS 2021; 9(1): 936-941

(C) 2021 IJCS

Received: 06-10-2020

Accepted: 15-12-2020

\section{Ronanki Divya}

PG Research Scholar,

Department of Horticulture,

M.S. Swaminathan School of

Agriculture, Centurion

University of Technology and

Management, Paralakhemundi,

Odisha, India

\section{K Mallikarjunarao}

Assistant Professor, Department

of Horticulture, M.S.

Swaminathan School of

Agriculture, Centurion

University of Technology and

Management, Paralakhemundi,

Odisha, India

\section{Barsha Tripathy}

Assistant Professor, Department

of Horticulture, M.S.

Swaminathan School of

Agriculture, Centurion

University of Technology and

Management, Paralakhemundi,

Odisha, India

\section{Praveen Kumar}

Assistant Professor, Department of Genetics and Plant Breeding,

M.S. Swaminathan School of

Agriculture, Centurion

University of Technology and

Management, Paralakhemundi,

Odisha, India

Corresponding Author:

Ronanki Divya

PG Research Scholar,

Department of Horticulture,

M.S. Swaminathan School of

Agriculture, Centurion

University of Technology and

Management, Paralakhemundi,

Odisha, India

\section{Correlation and path coefficient analysis in brinjal (Solanum melongena L.)}

\section{Ronanki Divya, K Mallikarjunarao, Barsha Tripathy and Praveen Kumar}

DOI: https://doi.org/10.22271/chemi.2021.v9.i1m.11348

\begin{abstract}
A field experiment including fifteen brinjal genotypes was conducted at Bagusala (Village) instructional farm, Paralakhemundi, Department of Horticulture, M.S. Swaminathan School of Agriculture, Centurion University of Technology and Management during the rabi season of 2019-20. The observations were recorded on both quantitative and qualitative traits. Study on correlation between several characters shows that selection for fruit yield must based on plant height, plant spread (E-W), plant spread (N-S), stem girth, fruit length, fruit girth, fruit weight, number of fruits plant ${ }^{-1}$, fruit and shoot borer, pericarp thickness, flesh thickness, vitamin $\mathrm{C}$ and dry matter. In present study genotypic correlation was observed to be higher than the corresponding phenotypic correlations for all the character combinations and therfore it shows that the suppression of phenotypic expression under the influence of environmental factors. Path coefficient analysis of total fruit yield contributing attributes estimated that fruit length, showed maximum positive direct effect followed by vitamin $\mathrm{C}$, pericarp thickness, number of primary branches plant ${ }^{-1}$, fruit weight, days to first flowering, TSS, stem girth and number of fruits plant ${ }^{-1}$ which indicated that these traits have to give much importance in selection programme for yield improvement in brinjal.
\end{abstract}

Keywords: Brinjal, correlation and path analysis

\section{Introduction}

Brinjal or Aubergine or Eggplant (Solanum melongena L., $2 \mathrm{n}=24$ ) belongs to the family Solanaceae which is one of the most important commercial vegetable crops all over the world, especially in the tropics and subtropics (Kalloo, 2002) ${ }^{[4]}$. For diabetic patients consumption of white brinjal is good. In India brinjal accounts an area of 726 million ha with a production of 12660000 metric tonnes. In Odisha brinjal was cultivated with an area of 117920 ha with a production of 2013020 tonnes. (Agriculture research data book, ICAR 2019). Brinjal or eggplant is perennial crop but commercially grown as annual crop. To determine the yield components correlation and path coefficient analysis are the chief biometrical techniques. The characters which are of positively correlated with yield are the most important to plant breeder for selection purpose. Correlation coefficient analysis appraises the mutual relationship between two plant characters and establishes the yield components upon which selection is to be done for improvement in yield (Koundinya and Dhankhar, 2013) ${ }^{[5]}$. Path analysis splits the correlation coefficients into the measure of direct and indirect effects and consequently providing an understanding of the direct and indirect contribution of each character towards yield. So, keeping this in view, the present investigation was under taken together with the objective inorder to understand the character association between the various characters as well as their direct and indirect effects on yield in brinjal. The details on corresponding aspects can be of great help in formulating an appropriate breeding strategy for genetic upgrading of this commercial vegetable crop.

\section{Materials and Methods}

The experiment was conducted at Bagusala (Village) instructional farm, Paralakhemundi, Department of Horticulture, M.S. Swaminathan School of Agriculture, Centurion University of Technology and Management. The experimental material consisted of fifteen brinjal genotypes and they grow in a randomized block design with three replications. In each replication genotypes were allocated randomly. The unit plot size was $12 \mathrm{~m}^{2}$ (3 m X $\left.4 \mathrm{~m}\right)$. 
On the ridges of the rows plants were planted with a spacing of 60 among the rows and $45 \mathrm{~cm}$ between the plants. For each ridge six plants were planted. Recommended cultural practices are followed to raise a healthy crop. Choosing of five randomly selected plants in each replication for recording the observations, therefore the growth parameters viz., plant height $(\mathrm{cm})$, number of branches plant ${ }^{-1}$, plant spread $(\mathrm{E}-\mathrm{W})$ $(\mathrm{cm})$, plant spread $(\mathrm{N}-\mathrm{S})(\mathrm{cm})$, stem girth $(\mathrm{cm})$. Earliness parameters viz., days to first flowering, days to $50 \%$ flowering, days to first harvest. Yield parameters viz., number of fruits plant ${ }^{-1}$, fruit length $(\mathrm{cm})$, fruit girth $(\mathrm{cm})$, fruit weight $(\mathrm{g})$, fruit yield plant ${ }^{-1}(\mathrm{~kg})$. Pest incidence viz., fruit and shoot borer incidence (\%)and quality parameters viz., pericarp thickness (mm), flesh thickness (cm), TSS ( ${ }^{0}$ Brix), vitamin C $(\mathrm{mg} / 100 \mathrm{~g})$ and dry matter $(\mathrm{g})$. The correlation and path coefficient was given by using the formula of Dewey and Lu $(1959)^{[3]}$; Singh et al (2010) ${ }^{[13]}$.

\section{Results and Discussion}

The correlation among fruit yield per plant along with several yield attributes and among the characteristics were presented (Table 1 and 2). The phenotypic and genotypic correlation computed among nineteen characters. Out of nineteen characters, fruit yield plant ${ }^{-1}$ had positive and significant correlation with plant height $(0.697$ and 0.495$)$, plant spread (E-W) (0.785 and 0.575), plant spread (N-S) $(0.895$ and $0.707)$, stem girth $(0.718$ and 0.687$)$, fruit length $(0.835$ and $0.763)$, fruit girth $(0.766$ and 0.615$)$, fruit weight $(0.883$ and $0.817)$, number of fruits plant ${ }^{-1}(0.953$ and 0.871$)$, pericarp thickness $(0.863$ and 0.601$)$, flesh thickness $(0.825$ and 0.633$)$ and vitamin C (0.978 and 0.453) at both genotypic and phenotypic level of significance at 1 percent. Plant height resulted significant highly positive phenotypic and genotypic correlation to plant spread (N-S) $(0.483$ and 0.985$)$, stem girth (0.529 and 0.882$)$, fruit length (0.565 and 0.956$)$, number of fruits plant ${ }^{-1}(0.421$ and 0.683$)$, vitamin C (0.435 and 0.744). Number of primary branches plant ${ }^{-1}$ estimated significant highly positive phenotypic and genotypic correlation with number of fruits plant ${ }^{-1}(0.403$ and 0.553$)$, while fruit girth (0.610) showed significant positive genotypic correlation. Plant spread (E-W) recorded highly significant positive correlation with plant spread $(\mathrm{N}-\mathrm{S})(0.614$ and 0.932$)$, stem girth $(0.488$ and 0.685$)$, fruit length $(0.614$ and 0.961 , number of fruits plant ${ }^{-1}(0.561$ and 0.901$)$, pericarp thickness $(0.388$ and 0.643$)$, vitamin $\mathrm{C}(0.530$ and 0.838$)$ both at phenotypic and genotypic level. Plant spread (N-S) showed significant and highly positive phenotypic and genotypic correlation with stem girth (0.643 and 0.821), fruit length (0.769 and 0.979), fruit girth (0.536 and 0.659), fruit weight (0.533 and 0.738), number of fruits plant ${ }^{-1}(0.688$ and 0.848$)$, pericarp thickness (0.506 and 0.864), vitamin C (0.705 and 0.923). Stem girth recorded significant and highly positive phenotypic as well as genotypic correlation with fruit length $(0.636$ and 0.715$)$, fruit girth (0.547 and 0.702), fruit weight (0.628 and 0.656), flesh thickness (0.600 and 0.749), vitamin C (0.749 and 0.826). Days to first flowering showed highly significant positive phenotypic and genotypic correlation with days to $50 \%$ flowering ( 0.851 and 0.925$)$. Days to $50 \%$ flowering recorded negatively as well as highly significant phenotypic correlation to flesh thickness $(-0.387)$ and showed significant negative phenotypic correlation with fruit weight (-0.326), pericarp thickness (-0.350) and flesh thickness (-0.569 at genotypic level only. Days to first harvest recorded negatively significant genotypic correlation with fruit girth $(-0.376)$, pericarp thickness (-0.362), and flesh thickness (-0.301). Fruit length recorded positive and highly significant phenotypic and genotypic correlation with fruit weight (0.608 and 0.677), number of fruits plant $^{-1}$ (0.689 and 0.776), pericarp thickness (0.455 and 0.718$)$, vitamin $\mathrm{C}(0.862$ and 0.883$)$ and flesh thickness (0.439) across phenotypic level only. Fruit girth showed highly significant positive phenotypic correlation along with fruit weight (0.608 and 0.782), pericarp thickness (0.764 and 0.965$)$, flesh thickness $(0.755$ and 0.952$)$, vitamin C (0.583 and 0.789), dry matter (0.421 and 0.779) and number of fruits plant ${ }^{-1}(0.563)$ across phenotypic level. Fruit weight recorded positive highly significant phenotypic as well as genotypic correlation together with number of fruits plant ${ }^{-1}$ (0.601 and 0.646), pericarp thickness (0.531 and 0.977), flesh thickness (0.596 and 0.808), vitamin $\mathrm{C}(0.785$ and 0.864$)$ and dry matter (0.380) at phenotypic level. Number of fruits plant 1 resulted highly significant positive phenotypic as well as genotypic correlation along with pericarp thickness $(0.446$ and 0.817), flesh thickness (0.606 and 0.709), TSS (0.568 and $0.699)$, vitamin $C$ (0.766 and 0.853). Fruit and shoot borer incidence showed highly significant negative phenotypic as well as genotypic correlation together with pericarp thickness $(-0.503$ and $(-0.855)$, flesh thickness $(-0.717$ and (-0.868), vitamin C (-0.819 and -0.904). Pericarp thickness recorded positive and highly significant phenotypic as well as genotypic correlation along with flesh thickness $(0.548$ and $0.956)$, vitamin $C(0.557$ and 0.918$)$, dry matter $(0.402$ and 0.794). Flesh thickness recorded highly significant positive phenotypic and genotypic correlation with vitamin C $(0.647$ and 0.807$)$ and dry matter (0.451) at phenotypic level only. TSS showed significant positive phenotypic correlation with vitamin C (0.367 and 0.527). Vitamin C recorded highly significant positive phenotypic correlation with dry matter (0.434) and showed significant positive correlation with dry matter (0.578) at genotypic level. Dry matter showed only positive significant genotypic correlation with dry matter (0.531). Among those traits studied, strong inherent relationship was establishing and thus these findings were clearly shows that genotypic correlations were of higher magnitude to the corresponding phenotypic correlation. It can be concluded that the selection criteria based on vitamin $\mathrm{C}$ can provide better results for yield improvement in brinjal. Similar results were also obtained by Bansal and Mehta (2008) ${ }^{[2]}$, Patel (2001) ${ }^{[10]}$, Sarnaik et al. (1999) ${ }^{[11]}$ and Asati $(2001)^{[1]}$.

At both phenotypic and genotypic level the direct as well as indirect effects of several traits on fruit yield presented (Table 3 and 4). In phenotypic path, number of fruits plant ${ }^{-1}(0.507)$ resulted maximum positive direct effect followed by vitamin C (0.361), fruit weight (0.278), pericarp thickness (0.215), stem girth (0.076), plant height (0.071), plant spread (E-W) (0.059), days to first harvest $(0.046)$, plant spread (N-S) (0.029) and dry matter (0.022) showed that these are the main pioneer to fruit yield which is in consonance with the findings of Mishra et al. (2007) ${ }^{[6]}$ and shande et al. (2014) ${ }^{[12]}$. Plant height showed maximum positive and indirect effect on fruit yield plant ${ }^{-1}$ via, number of fruits plant ${ }^{-1}(0.214)$, vitamin C (0.157), fruit weight (0.098), pericarp thickness (0.067), stem girth (0.040), fruit and shoot borer (0.029), plant spread (EW) (0.019), plant spread (N-S) (0.014), days to first flowering $(0.003)$ and days to $50 \%$ flowering and dry matter $(0.000)$. Number of primary branches plant $^{-1}$ showed maximum positive and indirect effect on fruit yield plant $^{-1}$ via, number of fruits plant ${ }^{-1}(0.204)$, vitamin $C(0.085)$, pericarp thickness (0.062), fruit weight (0.055), fruit and shoot borer (0.030), plant height $(0.025)$, stem girth $(0.023)$, plant spread (E-W) 
(0.013), plant spread (N-S) (0.008), dry matter (0.006), days to first flowering (0.003) and days to $50 \%$ flowering (0.001). Plant spread (E-W) showed maximum positive as well as indirect effect on fruit yield plant ${ }^{-1}$ through number of fruits plant $^{-1}(0.285)$, vitamin $\mathrm{C}(0.192)$, fruit weight (0.097), pericarp thickness $(0.084)$, stem girth (0.037), fruit and shoot borer incidence (0.034), plant height $(0.024)$, plant spread $(\mathrm{N}-$ S) (0.018), days to first flowering (0.004), dry matter (0.002) and days to $50 \%$ flowering (0.000) while rest of the characters exhibited indirect negative values. Plant spread $(\mathrm{N}-\mathrm{S})$ had maximum positive and indirect effect on fruit yield plant ${ }^{-1}$ through number of fruits plant ${ }^{-1}(0.349)$, vitamin $C(0.255)$, fruit weight $(0.148)$, pericarp thickness $(0.108)$, fruit and shoot borer incidence (0.052), stem girth (0.049), plant spread (E-W) (0.036), plant height (0.034), dry matter (0.006), days to first flowering (0.004) and days to $50 \%$ flowering (0.000) while remaining traits exhibited indirect negative values. Stem girth recorded maximum positive and indirect effect on fruit yield plant ${ }^{-1}$ via, number of fruit plant ${ }^{-1}(0.272)$, vitamin C (0.271), fruit weight (0.174), pericarp thickness (0.079), fruit and shoot borer (0.052), plant height (0.038), plant spread (E-W) (0.028), plant spread (N-S) (0.019), days to first flowering (0.005), dry matter (0.003) and days to $50 \%$ flowering (0.001). Days to first flowering recorded positive indirect effect on fruit yield plant $^{-1}$ via, fruit length (0.084), fruit girth (0.065), flesh thickness (0.022), days to first harvest (0.009), number of primary branches plant ${ }^{-1}(0.006)$ and total soluble solids (0.004). Days to $50 \%$ flowering recorded positive indirect effect on fruit yield plant $^{-1}$ via, fruit length (0.075), fruit girth (0.056), flesh thickness (0.021), days to first harvest (0.011), total soluble solids (0.009) and number of primary branches plant ${ }^{-1}(0.008)$. Days to first harvest showed positive indirect effect on fruit yield plant ${ }^{-1}$ was reported highest via, fruit girth (0.074), fruit length and flesh thickness (0.016), number of primary branches plant ${ }^{-1}(0.008)$ and total soluble solids (0.001). Fruit length exhibited positive indirect effect on fruit yield plant ${ }^{-1}$ via, number of fruits plant ${ }^{-}$ 1 (0.349), vitamin C (0.310), fruit weight (0.169), pericarp thickness (0.099), fruit and shoot borer (0.051), stem girth (0.048), plant height (0.040), plant spread (E-W) (0.036), plant spread $(\mathrm{N}-\mathrm{S})(0.022)$, dry matter $(0.007)$, days to first flowering (0.006), and days to $50 \%$ flowering (0.001). Fruit girth had positive indirect effect on fruit yield plant ${ }^{-1}$ via, number of fruits plant ${ }^{-1}(0.286)$, vitamin $C(0.210)$, fruit weight (0.169), pericarp thickness $(0.165)$, fruit and shoot borer (0.051), stem girth (0.041), plant spread (E-W) (0.018), plant spread $(\mathrm{N}-\mathrm{S})(0.015)$, plant height $(0.014)$, dry matter (0.009), days to first flowering (0.006), and days to $50 \%$ flowering (0.001). The positive indirect effect of fruit weight on fruit yield plant $^{-1}$ recorded highest via, number of fruits plant $^{-1}(0.304)$, vitamin $C(0.283)$, pericarp thickness (0.114), fruit and shoot borer and stem girth (0.048), plant height (0.025), plant spread (E-W) (0.020), plant spread (N-S) (0.015), dry matter (0.008), days to first flowering (0.007) and days to $50 \%$ flowering $(0.001)$. Number of fruits plant ${ }^{-1}$ showed maximum positive indirect effect on fruit yield plant ${ }^{-1}$ via, vitamin C (0.275), fruit weight (0.167), pericarp thickness (0.097), fruit and shoot borer (0.064), stem girth (0.040), plant spread (E-W) (0.033), plant height (0.030), plant spread (N-S) (0.020), dry matter (0.006), days to first flowering (0.004), and days to $50 \%$ flowering (0.001). Fruit and shoot borer incidence had positive indirect effect on fruit yield plant ${ }^{-1}$ via, fruit length (0.181), fruit girth (0.134), flesh thickness (0.040), total soluble solids $(0.019)$, number of primary branches plant ${ }^{-}$ 1 (0.016) and days to first harvest (0.003). The positive indirect effect of pericarp thickness on fruit yield plant ${ }^{-1}$ was observed highest via, number of fruits plant ${ }^{-1}(0.226)$, vitamin C (0.200), fruit weight (0.147), fruit and shoot borer (0.037), stem girth (0.027), plant height and plant spread (E-W) (0.022), plant spread (N-S) (0.015), dry matter (0.009), days to first flowering (0.007) and days to 50\% flowering (0.001). Flesh thickness resulted maximum positive indirect effect on fruit yield plant ${ }^{-1}$ via, number of fruits plant ${ }^{-1}(0.307)$, vitamin C (0.233), fruit weight (0.165), pericarp thickness (0.118), fruit and shoot borer $(0.53)$, stem girth $(0.045)$, plant spread $(\mathrm{N}-\mathrm{S})(0.016)$, plant spread (E-W) (0.014), plant height (0.013), dry matter (0.010), days to first flowering (0.007), and days to $50 \%$ flowering $(0.001)$. Total soluble solids had positive indirect effect on fruit yield plant ${ }^{-1}$ via, number of fruits plant ${ }^{-1}(0.287)$, vitamin $\mathrm{C}(0.132)$, fruit weight (0.066), fruit and shoot borer (0.037), pericarp thickness (0.028), stem girth (0.017), plant spread (E-W) (0.020), plant spread (N-S) (0.007), dry matter and days to first flowering (0.002), and days to $50 \%$ flowering and plant height (0.001). Vitamin C showed maximum indirect positive effect on fruit yield plant ${ }^{-1}$ via, number of fruits plant $^{-1}(0.388)$, fruit weight $(0.218)$, pericarp thickness (0.119), fruit and shoot borer (0.061), stem girth (0.057), plant spread (E-W) and plant height (0.031), plant spread $(\mathrm{N}-\mathrm{S})(0.020)$, dry matter $(0.009)$, days to first flowering (0.004), and days to $50 \%$ flowering $(0.001)$. The positive indirect effect of dry matter on fruit yield plant ${ }^{-1}$ was observed highest via, vitamin $\mathrm{C}(0.156)$, number of fruits plant $^{-1}(0.153)$, fruit weight $(0.105)$, pericarp thickness (0.086), fruit and shoot borer (0.024), stem girth (0.012), plant spread (N-S) (0.008), days to first flowering (0.007), plant spread (E-W) (0.005), plant height (0.003) and days to $50 \%$ flowering (0.001).

In case of genotypic path, fruit length (1.040) recorded maximum direct positive effect accompanied by vitamin $\mathrm{C}$ (0.530) pericarp thickness (0.453), number of primary branches plant ${ }^{-1}(0.321)$, fruit weight $(0.197)$, days to first flowering (171), TSS (0.149), stem girth (0.054) and number of fruits plant ${ }^{-1}(0.003)$ showed that these are the pioneers to fruit yield which is in accordance with the findings of Mishra et al. (2007) ${ }^{[6]}$, Naliyadhara et al. (2007) ${ }^{[7]}$ and shande et al. (2014) ${ }^{[12]}$. Plant height estimated that maximum positive and indirect effect on fruit yield plant $^{-1}$ via, fruit length (1.045), vitamin C (0.393), fruit and shoot borer (0.255), pericarp thickness (0.196), fruit weight (0.123), stem girth (0.048), number of primary branches plant ${ }^{-1}(0.020)$, days to $50 \%$ flowering (0.018), TSS (0.011), number of fruits plant ${ }^{-1}$ (0.002) and days to first harvest $(0.001)$. Number of primary branches plant ${ }^{-1}$ recorded maximum positive as well as indirect effect on fruit yield plant ${ }^{-1}$ via, fruit length (0.299), pericarp thickness $(0.237)$, vitamin $C(0.159)$, fruit and shoot borer (0.182), fruit weight (0.039), plant height $(0.025)$, stem girth $(0.022)$, days to $50 \%$ flowering $(0.017)$ as well as number of fruits plant ${ }^{-1}(0.001)$. Plant spread (E-W) had positive and indirect effect on fruit yield plant ${ }^{-1}$ via, fruit length (0.999), vitamin C (0.444), pericarp thickness (0.292), fruit and shoot borer $(0.244)$, number of primary branches plant $^{-1}(0.107)$, fruit weight $(0.093)$, TSS (0.084), days to first harvest $(0.074)$, stem girth $(0.037)$, days to $50 \%$ flowering $(0.009)$ and number of fruits plant ${ }^{-1}(0.003)$. Plant spread (NS) had positive and indirect effect on fruit yield plant $^{-1}$ via, fruit length (1.018), vitamin C (0.489), pericarp thickness (0.392), fruit and shoot borer (0.269), number of primary branches plant ${ }^{-1}(0.162)$, fruit weight $(0.145)$, days to first harvest $(0.053)$, TSS $(0.052)$, stem girth $(0.044)$, days to $50 \%$ flowering $(0.015)$ as well as number of fruits plant ${ }^{-1}(0.002)$. 
Stem girth recorded maximum positive as well as indirect effect to fruit yield plant $^{-1}$ via, fruit length (743), vitamin C (0.437), pericarp thickness (0.307), fruit and shoot borer (0.256), number of primary branches plant ${ }^{-1}(0.131)$, fruit weight $(0.129)$, days to first harvest $(0.029)$, TSS $(0.045)$, days to $50 \%$ flowering (0.014) and number of fruits plant ${ }^{-1}$ (0.001). Days to first flowering recorded indirect positive effect on fruit yield plant $^{-1}$ via, plant spread (N-S) (0.221), fruit girth (0.175), dry matter (0.125), Plant height (0.114), flesh thickness (0.104), plant spread (E-W) (0.050). Days to $50 \%$ flowering recorded indirect positive effect on fruit yield plant ${ }^{-1}$ viz., fruit girth (0.173), days to first flowering (0.171), plant spread (N-S) (0.147), dry matter (0.113), flesh thickness (0.104), Plant height (0.079) and plant spread (E-W) (0.039). The positive indirect effect of days to first harvest on fruit yield plant ${ }^{-1}$ was reported highest via, fruit girth (0.179), plant spread (N-S) (0.146), and plant spread (E-W) (0.088), dry matter (0.079), flesh thickness (0.076), days to first flowering (0.056) and plant height (0.001). Fruit length showed positive indirect effect on fruit yield plant ${ }^{-1}$ via, vitamin C (0.468), pericarp thickness $(0.325)$, fruit and shoot borer $(0.249)$, fruit weight (0.133), number of primary branches plant ${ }^{-1}(0.092)$, TSS (0.058), stem girth (0.039), days to first harvest (0.006), days to $50 \%$ flowering and number of fruits plant ${ }^{-1}(0.002)$. Fruit girth showed positive indirect effect on fruit yield plant ${ }^{-1}$ via, fruit length (0.510), pericarp thickness (0.475), vitamin c (0.468), fruit and shoot borer (0.275), number of primary branches plant ${ }^{-1}(0.196)$, fruit weight $(0.154)$, days to first harvest $(0.108)$, TSS $(0.058)$, stem girth $(0.038)$, days to $50 \%$ flowering (0.028) and number of fruits plant ${ }^{-1}(0.002)$. The indirect positive effect of fruit weight on fruit yield plant ${ }^{-1}$ was reported highest via, fruit length (0.703), pericarp thickness (0.443), vitamin C (0.458), fruit and shoot borer $(0.242)$, number of primary branches plant ${ }^{-1}(0.065)$, days to first harvest (0.052), TSS (0.036), stem girth (0.035), days to $50 \%$ flowering $(0.028)$ and number of fruits plant ${ }^{-1}(0.002)$. Number of fruits plant ${ }^{-1}$ recorded indirect positive effect on fruit yield plant ${ }^{-1}$ via, fruit length $(0.798)$, vitamin C (0.452), pericarp thickness (0.371), fruit and shoot borer (0.292), number of primary branches plant ${ }^{-1}(0.177)$, fruit weight (0.127), TSS (0.104), days to first harvest (0.071), stem girth (0.030), days to $50 \%$ flowering (0.024) and number of fruits plant $^{-1}(0.002)$. Fruit and shoot borer incidence recorded indirect positive effect on fruit yield plant ${ }^{-1}$ via, plant spread $(\mathrm{N}-\mathrm{S})(0.500)$, fruit girth (0.307), plant height $(0.210)$, plant spread (E-W) (0.200), flesh thickness (0.161), dry matter (0.131) and days to first flowering (0.054). Pericarp thickness showed positive indirect effect on fruit yield plant ${ }^{-1}$ via, fruit length (0.747), vitamin C (0.486), fruit and shoot borer (0.283), fruit weight (0.193), number of primary branches plant $^{-1}(0.168)$, days to first harvest $(0.133)$, stem girth (0.037), days to $50 \%$ flowering (0.030), TSS (0.024) and number of fruits plant ${ }^{-1}(0.002)$. Flesh thickness showed positive indirect effect on fruit yield plant $^{-1}$ via, fruit length (0.509), vitamin C (0.427), fruit and shoot borer (0.288), number of primary branches plant ${ }^{-1}(0.163)$, fruit weight (0.159), days to first harvest (0.094), TSS (0.064), stem girth (0.040), days to $50 \%$ flowering (0.035) and number of fruits plant $^{-1}(0.002)$. The indirect positive effect of TSS on fruit yield plant ${ }^{-1}$ was reported highest via, fruit length (0.408), vitamin C (0.279), fruit and shoot borer (0.201), fruit weight (0.048), pericarp thickness (0.073), days to first harvest (0.018), stem girth $(0.016)$, days to $50 \%$ flowering $(0.012)$ and number of fruits plant ${ }^{-1}(0.002)$. Vitamin $\mathrm{C}$ showed maximum positive indirect effect on fruit yield plant $^{-1}$ via, fruit length (0.918), pericarp thickness (0.416), fruit and shoot borer $(0.300)$, fruit weight $(0.170)$, number of primary branches plant ${ }^{-1}(0.096)$, TSS $(0.078)$, stem girth (0.045), days to first harvest $(0.038)$, number of fruits plant $^{-1}$ and days to $50 \%$ flowering (0.002). Dry matter showed maximum positive indirect effect on fruit yield plant ${ }^{-1}$ via, fruit length (0.501), pericarp thickness $(0.360)$, vitamin $C(0.306)$, fruit and shoot borer $(0.187)$, fruit weight $(0.096)$, days to first harvest $(0.077)$, number of primary branches plant ${ }^{-1}(0.063)$, stem girth (0.013), TSS (0.006), days to $50 \%$ flowering $(0.003)$ and number of fruits plant ${ }^{-1}(0.001)$.

Table 1: Phenotypic correlation matrix table

\begin{tabular}{|c|c|c|c|c|c|c|c|c|c|c|c|c|c|c|c|c|c|c|c|}
\hline Path Matrix & PH & PB & PSE-W & Ps N-S & \begin{tabular}{|l|} 
SG \\
\end{tabular} & DFF & D50\% F & DFH & \begin{tabular}{|c|} 
FL \\
\end{tabular} & FG & F W & \begin{tabular}{|l|} 
NF \\
\end{tabular} & F\&S & PT & FT & TSS & Vit C & DM & FY \\
\hline PH & 1 & $0.351 *$ & $0.335 *$ & $0.483 * *$ & $0.529 * *$ & -0.187 & \begin{tabular}{|l|}
-0.083 \\
\end{tabular} & -0.161 & $0.565^{* * *}$ & 0.205 & $0.354 *$ & $0.421^{* * *}$ & $-0.392 * *$ & $0.309 *$ & 0.192 & 0.022 & 0.435 ** & 0.041 & $0.495^{* * *}$ \\
\hline PB & & 1 & 0.233 & 0.293 & $0.313 *$ & -0.154 & -0.224 & -0.209 & 0.202 & $0.323 *$ & 0.201 & \begin{tabular}{|l|l|}
$0.403 * *$ \\
\end{tabular} & $-0.412 * *$ & 0.285 & $0.319 *$ & 0.025 & 0.235 & $0.299 *$ & \begin{tabular}{|l|}
0.335 \\
\end{tabular} \\
\hline PS E-W & & & 1 & $0.614 * *$ & $0.488 * *$ & -0.207 & -0.172 & -0.074 & |0.614*** & $0.318 *$ & $0.352^{*}$ & $0.561 * * \mid$ & $-0.464 * *$ & $0.388 * *$ & 0.240 & $0.353 *$ & 0.530 ** & 0.092 & $0.575^{* * *}$ \\
\hline Ps N-S & & & & 1 & 0.643 *** & $\mid-0.238$ & -0.183 & -0.175 & 0.769 *** & $0.536^{* * *}$ & $0.533^{* * *}$ & $0.688 * * \mid$ & $-0.689 * *$ & 0.506 ** & $0.537 * *$ & 0.259 & $0.705^{* * *}$ & 0.283 & $0.707^{* * *}$ \\
\hline SG & & & & & \begin{tabular}{|l|}
1 \\
\end{tabular} & -0.257 & \begin{tabular}{|l|}
-0.185 \\
\end{tabular} & -0.096 & $0.636 * * \mid$ & 0.547 ** & $0.628 * *$ & $0.535 * * \mid$ & $-0.705^{* *}$ & $0.363^{*}$ & $0.600 * *$ & 0.227 & $0.749 * *$ & \begin{tabular}{|l|l}
0.163 \\
\end{tabular} & $0.687^{* * *}$ \\
\hline DFF & & & & & & 1 & 0.851 ** & 0.196 & $\mid-0.318 *$ & $-0.336 *$ & \begin{tabular}{|l|}
$-0.351 *$ \\
\end{tabular} & \begin{tabular}{|l|}
-0.207 \\
\end{tabular} & 0.250 & $-0.355^{*}$ & $-0.399 * *$ & -0.117 & \begin{tabular}{|l|}
-0.245 \\
\end{tabular} & $-0.363 *$ & \begin{tabular}{|l|}
-0.28 \\
\end{tabular} \\
\hline D50\%F & & & & & & & 1 & 0.253 & \begin{tabular}{|l|}
-0.287 \\
\end{tabular} & -0.288 & $-0.326^{*}$ & -0.257 & 0.258 & $-0.350 *$ & -0.387 ** & -0.236 & -0.266 & -0.231 & -0.293 \\
\hline DF H & & & & & & & & 1 & \begin{tabular}{|l|}
-0.062 \\
\end{tabular} & -0.376 * & -0.197 & -0.27 & 0.083 & $-0.362 *$ & $-0.301 *$ & -0.043 & -0.154 & -0.210 & -0.206 \\
\hline FL & & & & & & & & & 1 & $0.374 *$ & 0.608 ** & \begin{tabular}{|l|l|}
$0.689 * *$ \\
\end{tabular} & $-0.695 * *$ & $0.455 * *$ & $0.439 * *$ & 0.234 & $0.862 * *$ & $0.323 *$ & $0.763^{* *}$ \\
\hline FG & & & & & & & & & & 1 & $0.608 * *$ & \begin{tabular}{|l|}
$0.563^{* * *}$ \\
\end{tabular} & $-0.687^{* *}$ & $0.764 * *$ & $0.755 * *$ & 0.193 & $0.583^{* * *}$ & $0.421 * *$ & $0.615^{* * *}$ \\
\hline $\mathrm{FW}$ & & & & & & & & & & & \begin{tabular}{|l|}
1 \\
\end{tabular} & \begin{tabular}{|l|}
$0.601 * *$ \\
\end{tabular} & $-0.646^{* *}$ & $0.531 * *$ & 0.596 ** & 0.237 & $0.785^{* * *}$ & $0.380 * *$ & $0.817^{* * *}$ \\
\hline $\mathrm{NF}$ & & & & & & & & & & & & 1 & $-0.841 * *$ & $0.446 * *$ & $0.606 * *$ & $0.568 * *$ & \begin{tabular}{|l}
$0.766^{* * *}$ \\
\end{tabular} & $0.303 *$ & $0.871^{* * *}$ \\
\hline F\&S & & & & & & & & & & & & & 1 & $-0.503 * *$ & $-0.717 * *$ & $-0.504 * *$ & $-0.819 * *$ & $-0.326 *$ & $-0.831^{* * *}$ \\
\hline PT & & & & & & & & & & & & & & 1 & $0.548 * *$ & \begin{tabular}{|l|}
0.134 \\
\end{tabular} & 0.557 ** & $0.402 * * \mid$ & $0.601 * *$ \\
\hline Path Matrix & $\mathrm{PH}$ & PB & PSE-W & Ps N-S & SG & DFF & D50\% F & DFH & FL & FG & F W & $\mathrm{NF}$ & $\mathrm{F} \& \mathrm{~S}$ & PT & FT & TSS & Vit C & \begin{tabular}{|l|} 
DM \\
\end{tabular} & FY \\
\hline $\mathrm{FT}$ & & & & & & & & & & & & & & & 1 & 0.230 & 0.647 ** & $0.451 * *$ & $0.633^{* * *}$ \\
\hline TSS & & & & & & & & & & & & & & & & 1 & $0.367 *$ & \begin{tabular}{|l|}
0.109 \\
\end{tabular} & $0.453^{* * *}$ \\
\hline Vit $\mathrm{C}$ & & & & & & & & & & & & & & & & & 1 & $0.434 * *$ & $0.898^{* *}$ \\
\hline DM & & & & & & & & & & & & & & & & & & & $0.369^{*}$ \\
\hline
\end{tabular}

* and ** indicate at 5 and 1 percent probability level, respectively

$\mathbf{P H}=$ Plant height, $\mathbf{P B}=$ Primary branches, $\mathbf{P s}(\mathbf{E}-\mathbf{W})=$ Plant spread (East-west), Ps $(\mathbf{N}-\mathbf{S})=$ Plant spread (North-south), $\mathbf{S G}=\mathbf{S t e m}$ girth, $\mathbf{D F F}=$ Days to $1^{\text {st }}$ flowering, D50\% F = Days to 50 percent flowering, $\mathbf{D F H}=$ Days to $1^{\text {st }}$ harvest, $\mathbf{F L}=$ Fruit length, $\mathbf{F G}=$ Fruit girth, $\mathbf{F W}=$ Fruit weight, $\mathbf{N F}=$ Number of fruits plant ${ }^{-1}, \mathbf{F} \& \mathbf{S}=$ Fruit and shoot borer incidence, $\mathbf{P T}=$ Pericarp thickness, $\mathbf{F T}=$ Flesh thickness, TSS=Total soluble solids,

Vit $\mathbf{c}=$ Vitamin $\mathbf{C}, \mathbf{D M}=$ Dry matter.

Table 2: Genotypic correlation matrix table

\begin{tabular}{|c|c|c|c|c|c|c|c|c|c|c|c|c|c|c|c|c|c|c|c|}
\hline Path Matrix & $\mathbf{P H}$ & \begin{tabular}{|l|} 
PB \\
\end{tabular} & PSE-W & Ps N-S & SG & DFF & D50\%F & DFH & FL & FG & F W & NF & F\&S & PT & FT & TSS & Vit C & DM & FY \\
\hline $\mathrm{PH}$ & 1 & $0.622 *$ & $0.925^{* *}$ & $0.935^{* *}$ & $0.882 * *$ & -0.420 & -0.289 & -0.006 & $0.952 * *$ & 0.423 & $0.624 *$ & $0.693^{* *}$ & $-0.770 * *$ & 0.433 & 0.451 & 0.079 & $0.744^{* *}$ & 0.164 & $0.696 * *$ \\
\hline PB & & 1 & 0.335 & 0.506 & 0.409 & -0.214 & -0.274 & -0.411 & 0.288 & $0.610 *$ & 0.202 & $0.553 *$ & $-0.547 *$ & $0.523 *$ & 0.507 & -0.088 & 0.301 & 0.198 & 0.384 \\
\hline
\end{tabular}




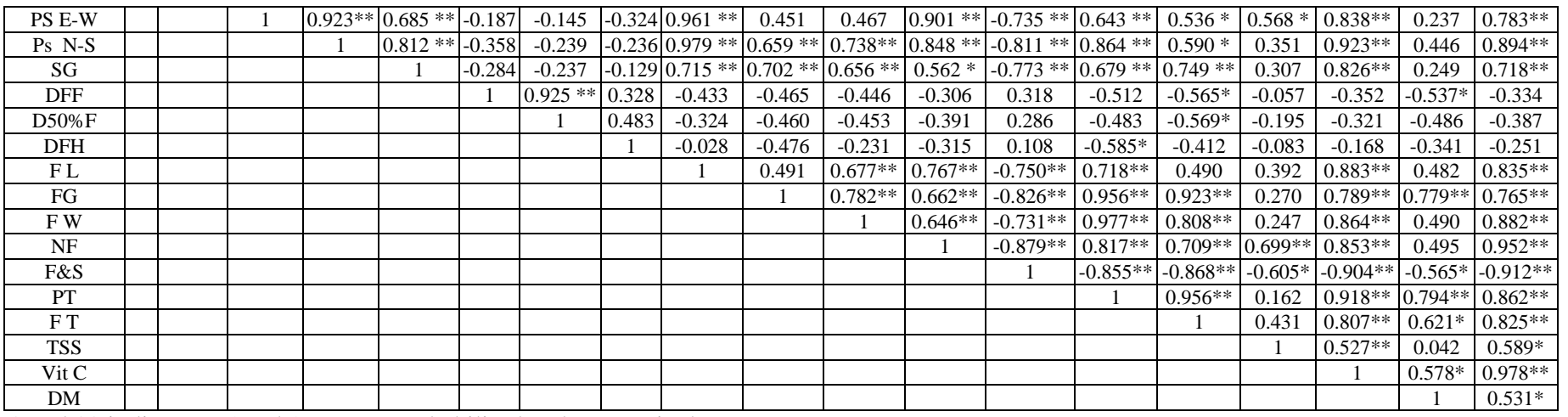

$*$ and $* *$ indicate at 5 and 1 percent probability level, respectively.

$\mathbf{P H}=$ Plant height, $\mathbf{P B}=$ Primary branches, $\mathbf{P s}(\mathbf{E}-\mathbf{W})=$ Plant spread (East-west), $\mathbf{P s}(\mathbf{N}-\mathbf{S})=$ Plant spread (North-south), $\mathbf{S G}=\mathbf{S t e m}$ girth, $\mathbf{D F F}=$

Days to $1^{\text {st }}$ flowering, D50\% F = Days to 50 percent flowering, $\mathbf{D F H =}$ Days to $1^{\text {st }}$ harvest, $\mathbf{F L}=$ Fruit length, $\mathbf{F G}=$ Fruit girth, $\mathbf{F W}=$ Fruit weight,

$\mathbf{N F}=$ Number of fruits plant ${ }^{-1}, \mathbf{F} \& \mathbf{S}=$ Fruit and shoot borer incidence, $\mathbf{P T}=$ Pericarp thickness, $\mathbf{F T}=$ Flesh thickness, TSS=Total soluble solids,

Vit $\mathbf{c}=$ Vitamin $\mathbf{C}, \mathbf{D M}=$ Dry matter.

Table 3: Phenotypic path matrix

\begin{tabular}{|c|c|c|c|c|c|c|c|c|c|c|c|c|c|c|c|c|c|c|c|}
\hline ath Matrix & PH & PB & DCF & Ps N-S & SG & DF F & D50\% & f DFH & FL & FG & F W & NF & F\&S & PT & FT & TSS & Vit C & DM & FY \\
\hline $\mathrm{PH}$ & 0.071 & -0.013 & 0.019 & 0.014 & 0.040 & 0.003 & 0.000 & $\mid-0.007$ & -0.147 & -0.041 & 0.098 & 0.214 & 0.029 & 0.067 & -0.010 & -0.000 & 0.157 & & \\
\hline B & & & & & & & & & & & & & & & & & & & \\
\hline E-W & 024 & -0.091 & 0. & 018 & 0.037 & 0.004 & 0.000 & -0.0 & & & & & $\lcm{34}$ & 0.084 & & & & 2 & \\
\hline$\overline{\mathrm{P}}$ & 334 & -0.011 & 0.036 & 029 & 0.049 & 0.004 & 0.000 & & & & & & 0.052 & & & & & & 707 \\
\hline $\mathrm{G}$ & 53 & -0.012 & 0.028 & 0.019 & 0.07 & 0.005 & 0.0 & -0.0 & & & & 0.272 & 0.052 & 0.079 & & & 271 & 0.003 & .081 \\
\hline $\mathrm{FF}$ & & & & 7 & -0.0 & & & & & & & & & & & & & & \\
\hline & 0.0 & & & 5 & & & & & & & & & & & & & & & \\
\hline $\mathrm{FH}$ & -0.011 & 0.008 & & 005 & & & & 0.046 & 0.016 & 0.074 & & & -0.006 & & & 0.001 & & & \\
\hline $\mathrm{L}$ & 0.040 & -0.007 & 0.036 & 022 & 0.048 & 0.0 & & -0.002 & -0.262 & -0.073 & & 0.3 & 0.051 & 0.099 & & -0.009 & & & .763 \\
\hline $\mathrm{G}$ & 014 & -0.012 & 0 . & 5 & 0.041 & 0.006 & 0.0 & -0.01 & -0.0 & & & 0.286 & 0.051 & 0.165 & & -0.007 & & 0.009 & 0.615 \\
\hline W & & & & & 0 & & & & & & & & 0.048 & & & & & & 817 \\
\hline $\mathrm{F}$ & & & & & 0 & & & & & & & & 0.064 & 0.097 & & & & 0.006 & .871 \\
\hline$\& S$ & .028 & 0.016 & & & -0.0 & & & & & \begin{tabular}{|l|l|}
0.134 \\
\end{tabular} & -0.179 & -0.426 & -0.076 & -0.108 & 0.040 & 19 & 296 & 0.007 & -0.831 \\
\hline PT & .022 & -0.011 & 0.02 & 0.0 & 0.027 & 0.007 & 0.001 & -0.016 & -0.1 & -0.149 & & 0.226 & 0.037 & 0.215 & -0.03 & -0.005 & & 0.009 & 0.601 \\
\hline $\mathrm{T}$ & 013 & -0.012 & & & 0.04 & 0.007 & & $-0 .($ & & & & 0.307 & 0.053 & & & & & 0.010 & .633 \\
\hline & & & & & & & & -0.1 & & & & & 0.037 & & & & & & 45 \\
\hline & & & & & & & & -0. & & & & & & & & & & & \\
\hline DM & 003 & -0.011 & 0.005 & 0.008 & .012 & 0.007 & 0.001 & -0.009 & & .002 & .105 & 0.153 & 0.024 & 0.086 & 0.0 & & 56 & 0.022 & 0.369 \\
\hline
\end{tabular}

Residual value: 0.2316

$\mathbf{P H}=$ Plant height, $\mathbf{P B}=$ Primary branches, $\mathbf{P s}(\mathbf{E}-\mathbf{W})=$ Plant spread (Wast-west), Ps $(\mathbf{N}-\mathbf{S})=$ Plant spread (North-south), $\mathbf{S G}=\mathbf{S t e m}$ girth, $\mathbf{D F F}=$ Days to $1^{\text {st }}$ flowering, D50\% $\mathbf{F}=$ Days to 50 percent flowering, DFH= Days to $1^{\text {st }}$ harvest, $\mathbf{F L}=$ Fruit length, $\mathbf{F G}=$ Fruit girth, $\mathbf{F W}=$ Fruit weight, $\mathbf{N F}=$ Number of fruits plant ${ }^{-1}, \mathbf{F} \& \mathbf{S}=$ Fruit and shoot borer incidence, $\mathbf{P T}=$ Pericarp thickness, $\mathbf{F T}=$ Flesh thickness, TSS=Total soluble solids,

Vit $\mathbf{c}=$ Vitamin $\mathbf{C}, \mathbf{D M}=$ Dry matter

Table 4: Genotypic path matrix of FY

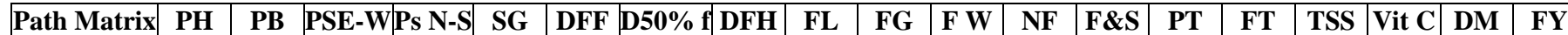

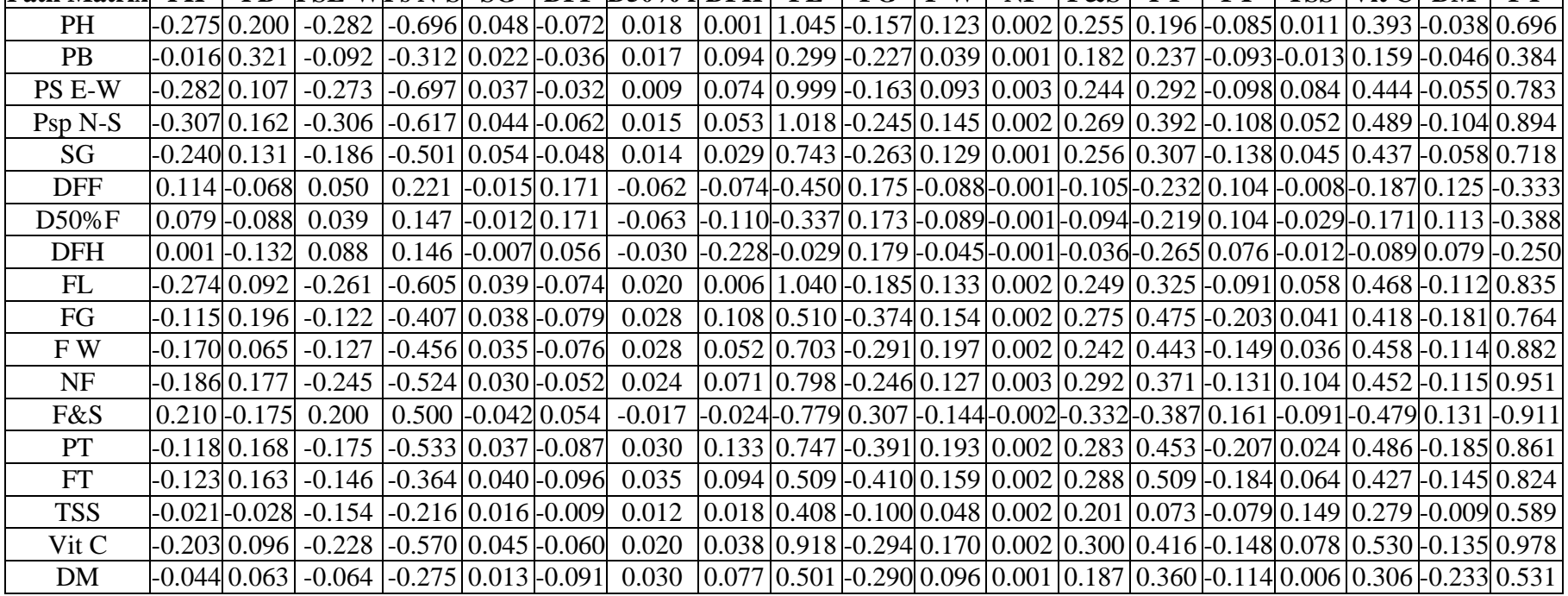
Residual value: 0.0192

$\mathbf{P H}=$ Plant height, $\mathbf{P B}=$ Primary branches, $\mathbf{P s}(\mathbf{E}-\mathbf{W})=$ Plant spread (Wast-west), Ps $(\mathbf{N}-\mathbf{S})=$ Plant spread $($ North-south), $\mathbf{S G}=\mathbf{S t e m}$ girth, $\mathbf{D F F}=$ Days to $1^{\text {st }}$ flowering, D50\% F = Days to 50 percent flowering, DFH= Days to $1^{\text {st }}$ harvest, $\mathbf{F L}=$ Fruit length, $\mathbf{F G}=$ Fruit girth, $\mathbf{F W}=$ Fruit weight, 
$\mathbf{N F}=$ Number of fruits plant ${ }^{-1}, \mathbf{F} \& \mathbf{S}=$ Fruit and shoot borer incidence, $\mathbf{P T}=$ Pericarp thickness, $\mathbf{F T}=$ Flesh thickness, TSS=Total soluble solids, Vit $\mathbf{c}=$ Vitamin $\mathbf{C}, \mathbf{D M}=$ Dry matter.

\section{Conclusion}

In present investigation genotypic correlation had observed to be higher than the corresponding phenotypic correlations for all the character combinations, it may due to environmental influence. From the present study path coeficient analysis of total fruit yield contributing characters estimated that the fruit length showed maximum positive direct effect followed by vitamin $\mathrm{C}$, pericarp thickness, number of primary branches plant $^{-1}$, fruit weight, days to first flowering, TSS, stem girth and number of fruits plant $^{-1}$. The selection based on these characters will results in development of high fruit yield plant ${ }^{-}$ 1

\section{References}

1. Asati BS. Evaluation of brinjal (round) varieties under chattisgarh condition. M.Sc. (Ag). Thesis submitted to Indira Gandhi Krishi Viswavidyalaya, Rajpur (C.G) 2001.

2. Bansal S, Nad Mehta AK. Genotypic correlation and path analysis in brinjal (Solanum melongena L.). National Journal of Plant Improvement 2008;10(1):34-36.

3. Dewey DR, Lu KH. A correlation and Path -Coefficient analysis of components of crested wheatgrass seed production. Agronomy Journal 1959;51(9):78.

4. Kallo G, Banerjee MK, Singh SN, Singh M. Genetics of yield and its component characters in brinjal (Solanum melongena L.). Vegetable science 2002;29:24-26.

5. Koundinya AVV, Dhankhar SK, Yadav AC. Genetic variability and divergence in okra (Abelmoschus esculentus). Indian Journal of Agricultural Science 2013;83(6):685-688.

6. Mishra SV, Warade SD, Nayakwadi MB. Correlation and path coefficient analysis in brinjal. Journal of Maharastra Agricultural Universities 2007;32(1):74-76.

7. Naliyadhara MV, Golani IJ, Mehta DR, Purohit VL. Genetic variability, correlation co-efficient and path analysis in brinjal. Orissa Journal of Horticulture 2007;35(2):92-96.

8. National Horticulture Data Base. National Horticulture Board, Ministry of Agriculture, Government of India 2019.

9. National Horticulture Data Base. National Horticulture Board, Ministry of Agriculture, Government of India 2019.

10. Patel KK. Evaluation and character association studies in long fruited genotypes on brinjal (Solanum melongena L.). M.Sc. (Ag) thesis. Indra Gandhi Krishi Vishwavidyalaya, Raipur 2001.

11. Saranaik DA, Verma SK, Verma DP. Correlation studies in (Solanum melongena L.). Advances in Horticulture and Forestry 1999;7:91-94.

12. Shande RA, Desai SS, Dalvi VV. Character association and path analysis in brinjal in brinjal (Solanum melongena L.). International Journal of Agricultural Sciences 2014;10(2):631-633.

13. Singh SK, Chowdhary DM, Shankar R. Correlation and path analysis in brinjal (Solanum melongena L.). Environment and Ecology 2010;28(3B):2022-2026. 